\title{
Sustainability of Enlarging EMU: Towards Endogeneity of OCA Criteria or Asymmetry of Shocks?
}

\author{
İmre Ersoy*
}

\section{Abstract:}

The EMU membership necessitates only the fulfillment of Maastricht Convergence Criteria and the 'Endogeneity of OCA criteria' hypothesis seems to be the silent code both behind its sustainability and enlargement. However, asymmetric shocks and the asymmetric transmission of the monetary policy of ECB may jeopardize the sustainability of EMU. The econometric analysis of co-integration of long term interest rates also puts forward the asymmetries of business cycles between EMU members, 7 years after its launch. In case of an asymmetric shock, the lack of flexibility of labor markets and the level of economic integration in some EMU members are prone to pose serious problems. In terms of real convergence, the GDP per capita of EMU members is diverging rather than converging. The dispersion of growth rates and the loss of competitiveness of some EMU members are also serious threats. The enlargement of EMU seems to further aggregate the problem as it will make the ECB's one monetary policy harder to fit to an enlarged all. The new EMU members will face a dilemma between nominal and real convergence due to their catching-up process. The EMU candidates are considered as small open economies, the problems of which would not even be felt in EMU, but the prospect EMU members will surely suffer at home in case of such asymmetries. The endogenity of OCA criteria might still slowly progress but asymmetric shocks will not wait for them to realize during the coming two or more decades. Thus, the new EU member states have to evaluate their economies also in terms of OCA criteria and real convergence and should be more cautios in their rush to EMU. In the euro zone, precautions should be taken for possible asymmetric shocks in terms of a sufficient federal budget and a system for fiscal transfers.

Keywords: EMU, Endogeneity of OCA criteria, Asymmetric Shocks, Real Convergence, Co-integration

\footnotetext{
* Asst. Prof. Dr., Marmara University, European Community Institute.
} 


\section{$\ddot{O}_{z e t:}$}

Avrupa Birliği üyeleri, Ekonomik ve Parasal Birliğe (EPB) üye olabilmek için sadece Maastricht Kriterlerine uymak zorundadırlar. Yeni 'Optimal Para Alanı'(OPA) teorisi de, OPA kriterlerine, para alanına dahil olunarak ulaşılabileceğini ileri sürmektedir. Halbuki, EPB üyeleri arasındaki asimetrik şoklar ve Avrupa Merkez Bankası (AMB) para politikasının ülkelere asimetrik aktarımı, EPB'in sürdürülebilirliğini tehlikeye düşürebilir. Bu çalışmada, EPB üyelerinin uzun dönem faiz oranlarındaki asimetrik dönemsellikler, Ekonometrik Eşbütünleşim analiziyle kanıtlanmıştır. Bu durum, asimetrik bir şokla karşılaşılması durumunda, işgücü piyasasında esnekliğin olmaması ve üye ülkelerin hiç değilse bir kısmı arasındaki düşük ekonomik entegrasyon düzeyi nedeniyle, EPB'de ciddi problemler yaşanması olasılığını doğurmaktadır. Reel yakınsama açısından bakıldığında, EPB üyelerinin kişi başına düşen Gayri Safi Milli Hasılalarının birbirine yaklaşmak yerine uzaklaştığını görmekteyiz. Ülkelerin büyüme oranları arasındaki farklılıklar ve bazı EPB üyelerinin rekabetçi güçlerindeki kayıplar da ciddi tehditler oluşturmaktadır. Bu şartlar altında EPB'in genişlemesi, varolan problemi daha da arttıracaktır çünkü AMB'ın tek para politikasının daha da genişlemiş bir EPB'e uygulanması işleri daha da zorlaştıracaktır. EPB'ye üye olma aşamasında ülkeler, nominal ve reel yakınsama hedefleri arasında ikilem içinde kalacaklardır. EPB'nin yeni üyelerinin küçük ve açık ekonomiler olduğu ve asimetrik şoklarla karşılaşsalar bile bunun EPB'i etkileyebilecek güçte olmayacağı düşünülmektedir. Ancak şurası kesindir ki, bu tarz bir şokla karşılaşılması durumunda sözkonusu ülke kendi içinde ciddi problemler yaşayacaktır. Ayrıca asimetrik şoklar da, yeni OPA teorisinin ileri sürdüğü , EPB'e dahil olarak sağlanacak yakınsamanın tamamlanması için gerekecek 20-30 yılı beklemeyeceklerdir. Dolayısıyla, EPB'e üye olacak ülkeler, ekonomilerini sadece Maastricht nominal kriterleri açısından değil, reel yakınsama kriterleri ve geleneksel OPA kriterlerine göre de değerlendirmeli ve EPB'e katılma konusunda daha temkinli olmalıdırlar. Avro alanındaki mevcut üye ülkeler ise muhtemel bir asimetrik şoka karşı, yeterli düzeyde bir federal bütçe oluşturarak ve mali transferler için bir sistem kurarak, önlem almalıdırlar.

Keywords: EPB, OPA Teorisi, Asimetrik Şoklar, Reel Yakınsama, Eşbütünleşim Analizi 


\section{Introduction}

The European Economic and Monetary Union is about to start its enlargement with the participation of Slovenia on the $1^{\text {st }}$ of January 2007 . $^{1}$ The new EU members will continue joining the EMU, once they fulfill the Maastricht Convergence Criteria. ${ }^{2}$ The enlargement seems will proceed rather quickly as the currencies of the majority of the new EU members are already in Exchange Rate Mechanism (ERM) II. $^{3}$

However, the debate on the sustainability of EMU is still vivid and it mainly focuses on the probability of asymmetric shocks in the enlarging EMU and the sufficiency of the fulfillment of Maastricht criteria for the success of EMU members. To join the European Economic and Monetary Union (EMU), the EU members have to fulfill only the nominal convergence criteria of Maastricht. Achieved real convergence is also expected although is not a predefined rule and the fulfillment of Optimum Currency Area (OCA) criteria is not required. Instead, the endogeneity hypothesis, which introduced the ex-post realization of OCA criteria through membership to a monetary union, started to be used as the main economic philosophy behind both the sustainability and the enlargement of EMU.

The aim of this paper is to discuss the sustainability of enlarging EMU. The remainder of the paper proceeds as follows: Section I evaluates the conventional and the new OCA theory. Section II analyses the current economic state of the present and prospect EMU members in terms of their

\footnotetext{
${ }^{1}$ The existing EMU members are 12 as Denmark and Britain used their "opt-outs" and Sweden does not attempt to meet the Maastricht convergence criteria by not participating to ERM II.

${ }^{2}$ The Maastricht Convergence Criteria are:
}

(a) no devaluation of its currency in the two years preceding the entrance into the union;

(b) inflation rate no higher than 1.5 percent above the average of the three countries with the lowest inflation rates;

(c)long-term interest rate not in excess of 2 percent above the average of the three countries with the lowest inflation rates and

(d) Government deficits and debts not exceeding 3 percent and 60 percent of the GDP, respectively.

${ }^{3}$ The 7 new EMU candidates who are already in ERM II do not have the right of opt-out. However, ERM II membership realizes upon the request of the country and countries have to be in ERM II for a minimum of two years. 
nominal convergence, real convergence and fulfillment of OCA criteria. Section III investigates if the path of EMU is more towards endogeneity of OCA criteria or asymmetry of shocks, by applying a co-integration analysis to one of the nominal convergence criteria of Maastricht, namely the long term interest rates. The paper concludes with some proposals for the enlargement and sustainability of EMU.

\section{The Optimum Currency Area Theory}

The traditional 'Optimum Currency Area' (OCA) theory is first developed by Mundel and further supplemented by Mc Kinnon and Kenen in 1960s. ${ }^{4}$ Optimum Currency Area can be defined as the geographic area for a single currency fluctuating as unity against other currencies, where exchange rate adjustments and sovereignty over monetary policy is no more required due to the existence of OCA properties and where current and future benefits of monetary integration exceeds its costs.

As countries lose the power of exchange rate adjustments and the autonomy over monetary policy by entering a monetary union, the traditional OCA theory suggests that countries should have trade, financial market, factor market, fiscal and political integration, price and wage flexibility, diversification in production and consumption as alternative means for adjustment in order to fight against asymmetric shocks. ${ }^{5}$

${ }^{4}$ For the conventional OCA Theory, see Mundell, R., 1968; Mundell, R., December 5 1997; Mc Kinnon, R., 2002; Mc Kinnon, R., 2004 ; Kenen, P., 2002

${ }^{5}$ The origins of the OCA theory are first developed by the 1999 Nobel Prize winner economist Mundell. The key focus of Mundell's OCA Theory was the search for mechanisms of adjustment to asymmetric shocks. His first contribution was mainly in terms of his defining the pros and cons of fixed vs. floating exchange rates and the need for a unified labor market as OCA criterion. Mc Kinnon argued that the nominal exchange rate would be less useful as an adjustment instrument for small economies in a monetary union as they would be more open and have less nominal rigidity. Kenen, on the other hand, put forward the need for fiscal integration and for diversification in production and consumption for the members of a monetary union to satisfy OCA criteria. Mundell in his later works emphasized the importance of risk sharing process by better reserve pooling and portfolio diversification in order to mitigate the risk of asymmetric shocks and in his studies in 1970s he (contrary to his previous works) became supportive of a larger monetary union. 
The gains and losses from participating to OCA can be shown in Figure $1 .^{6}$ The country should join the currency area if the degree of economic integration between its economy and that of currency area members is at least at point 1 .

\section{Figure 1: Conventional OCA Theory: The GG-LL Model}

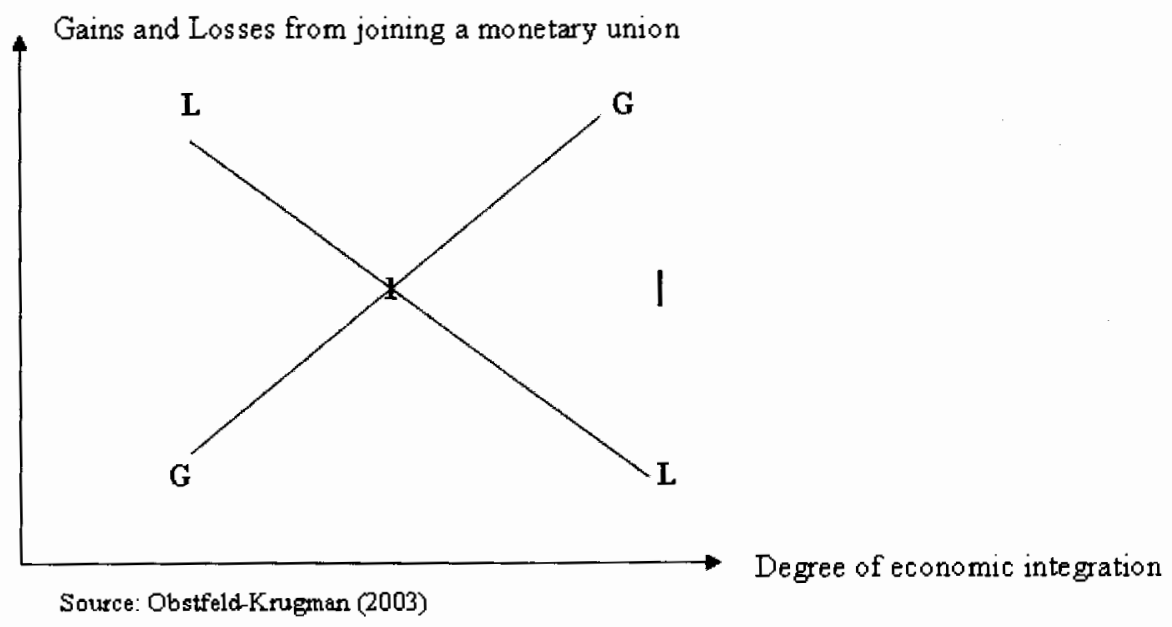

The conditions that are needed to make a monetary union attractive for candidates can be summarized by three concepts: flexibility (in labor markets), and integration (trade openness) in order to reduce the need for symmetry (in supply and demand shocks and business cycles).(De Grauwe, 2006a: 4)

\footnotetext{
${ }^{6}$ Mongelli, F., 2005 p. 612 "Benefits result principally from the increased usefulness of money, greater price transparency that will foster competition, the disappearance of intra-area nominal exchange rate uncertainty that will strengthen the internal market, foster trade, lower investment risks, and promote cross-area foreign direct investment (FDI), as well as enhance resource allocation. Other benefits will result from more transparent and deeper financial markets, savings on transactions costs, and a wider international circulation of the single currency. On the other side, there are Changeover Costs of switching to a new currency, increased administrative costs due to the creation of a supranational institution, and national governments will be prevented from equalizing the marginal cost of taxation and inflation. Membership of a currency area narrows the menu of policy instruments directly available to national governments"
} 
Figures 2 and 3 present combinations of symmetry -flexibility and symmetry-integration that are needed for an OCA. Figure 2 illustrates the trade-off between flexibility and symmetry and figure 3 demonstrates the trade-off between integration and symmetry. The countries on the right of the OCA-zone are those where benefits of a single currency exceed the costs.

\section{Figure 2: Symmetry and Flexibility as OCA Criteria}

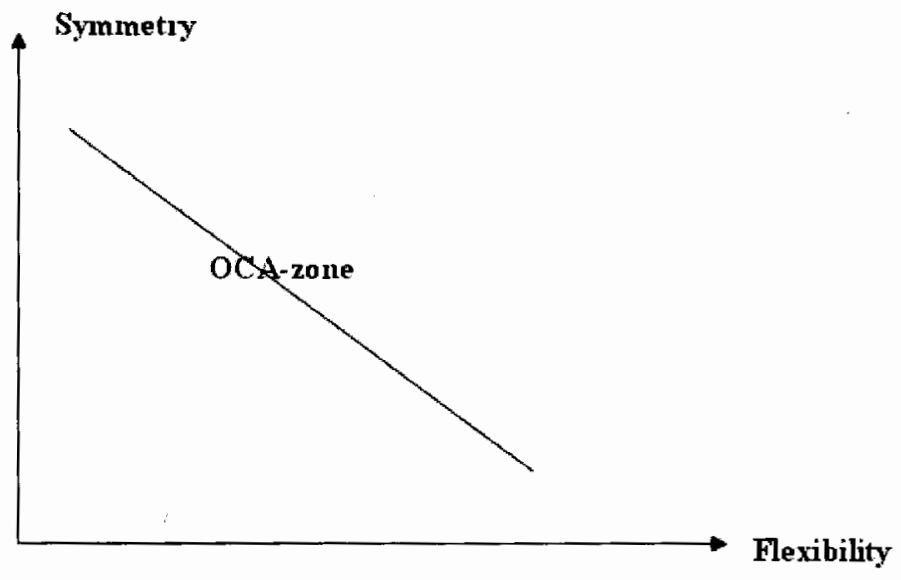

Source: De Grauwe (2006a)

Figure 3: Symmetry and Integration as OCA Criteria

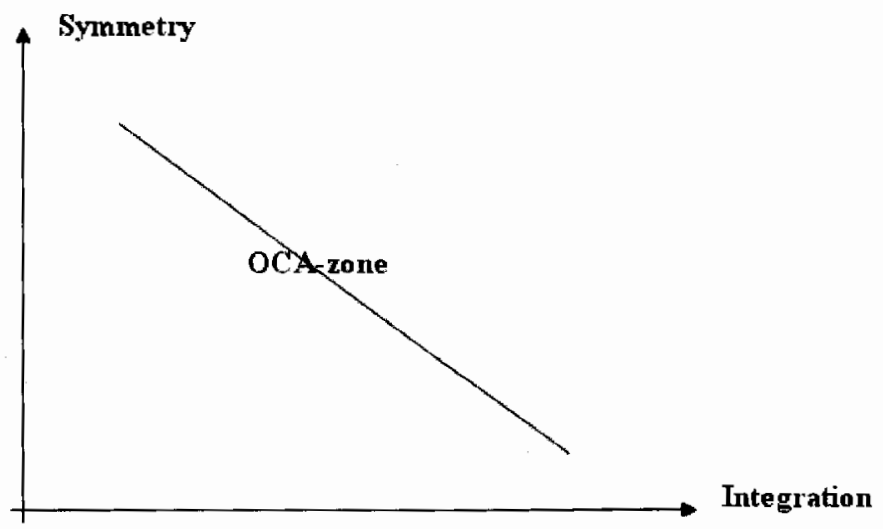

Source: De Grauwe (2006a)

However, Krugman, in line with the OCA criteria on the need for diversification of production and consumption, claims that the increase in economic integration will lead to more specialization in the industries and 
industry specific disturbances consequently will lead to more asymmetry in shocks across countries. ${ }^{7}$ Figure 4 illustrates the 'Specialization Hypothesis' of Krugman.

\title{
Figure 4: The Krugman Specialization Hypothesis
}

\author{
Correlation of business \\ cycles
}

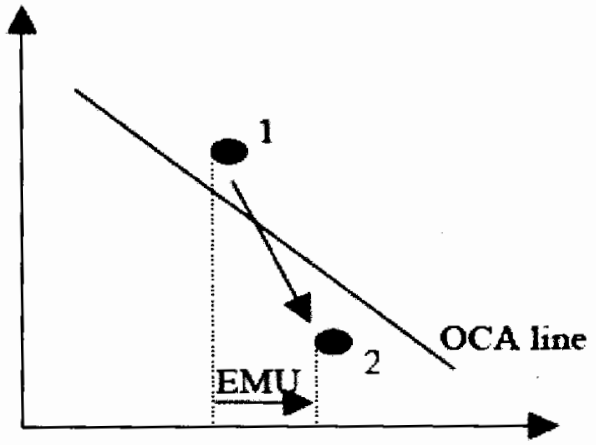

Degree of economic integration

Source: Kucerova (2003)

The OCA theory became once again the focus of attention by late 1990s in line with the developments in the European monetary integration. ${ }^{8}$ The new OCA theory has four contradicting results compared to the traditional OCA theory. First, the new OCA theory is based on the Monetarist critique of the Philips Curve which asserts that in the long run, monetary policies are already ineffective in controlling unemployment. ${ }^{9}$ Second, the new OCA theory is based on the view that exchange rates do not actually correct

${ }^{7}$ In this paper, the Krugman view will not further be developed as it invalidates all the further discussions on the subject.

${ }^{8}$ In 1960s the assumption was rather low capital mobility, but in 1990s the extent of capital mobility then existing is introduced to the theory. The importance of the introduction of the existing high capital mobility is important as according to the Mundell-Fleming model, in an.open economy, full capital mobility, fixed exchange rates and independent monetary policy are the impossible trinity.

${ }^{9}$ The traditional OCA theory, in line with the Phillips curve, was based on the assumption that countries in a monetary union would have the cost of not being able to fine tune the economy in terms of desired levels of unemployment and inflation. The Monetarist critique to Phillips curve, asserts that in the long run the Phillips curve is vertical and unemployment is related to the natural rate of unemployment. 
external imbalances perfectly and / or instantly. ${ }^{10}$ Third, the new OCA theory asserts that under the auspices of a credible central bank, a high inflation country joining the union is to receive a low inflation reputation without any cost. ${ }^{11}$ Fourth, the new OCA theory introduces the endogeneity of OCA criteria, arguing that many of the prerequisites for monetary union, the OCA properties, are in fact reinforced by the creation of a monetary union hence they realize ex post rather than ex ante as shown in figure 5. (Frankel and Rose, 1996:3)

\section{Figure 5: The Endogenity Hypothesis}

Correlation of Business Cycles

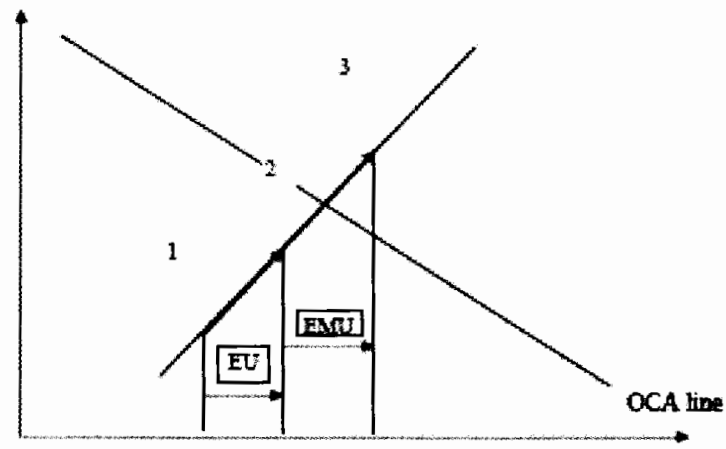

Degree of Economic Integration

Source: De Grauwe and Mongelli (2005)

The endogeneity of OCA criteria suggests that the OCA criteria realize ex-post rather than ex-ante. If countries which are on the left of the OCA line join together like in the case of EU, they move to point 2 . If the same countries start a monetary union then the trade integration and symmetry in the union would rise even more and the group will find itself subsequently on the right of the OCA line. The proponents of the theory claim that the countries do not have to fulfill the OCA criteria before they join a monetary union because both the trade integration and symmetry will increase when they join in. The theory also embodies the view that the new EU members should not wait long for EMU membership as once they fulfill the Maastricht criteria and enter EMU; the fulfillment of OCA criteria will follow endogeneously. Hence, the new OCA theory made changes in the perceived benefits and losses of monetary unification.

\footnotetext{
${ }^{10}$ Thus these two views of the new OCA theory already minimize the role of the sovereignty of both the monetary policy and particularly the exchange rate tool for the country- wise macroeconomic readjustment.

11 This new OCA theory is based on the expectations theory.
} 


\section{The Current State of present and prospect EMU members}

Maastricht Convergence Criteria require certain degree of nominal convergence before the inclusion in EMU. However, for the success of individual countries, there are other questions to be answered. What is the level of fulfillment of OCA criteria of the country? What is the level of its real convergence? Will it be able to sustain its competitiveness in the internal market? Will the monetary policy of ECB fit the needs of the country? Will it be exposed to asymmetric shocks in EMU? Will its market enable the country to react properly to the shocks? In order to find answers to these questions, the current economic state of present and prospect EMU members will be examined for their nominal convergence, real convergence and the ex-ante or ex-post realization of OCA criteria.

\subsection{Nominal Convergence}

Fulfillment of nominal convergence criteria will be evaluated only for fiscal discipline as after EMU membership, convergence of inflation and interest rates fall out of the scope of the Stability and Growth Pact (SGP). However, for the econometric analysis conducted in section 3, the following illustration is needed to show how perfectly the long term interest rate criteria of Maastricht is fulfilled.

\section{Graph 1: Long term interest rates 1997-2004}
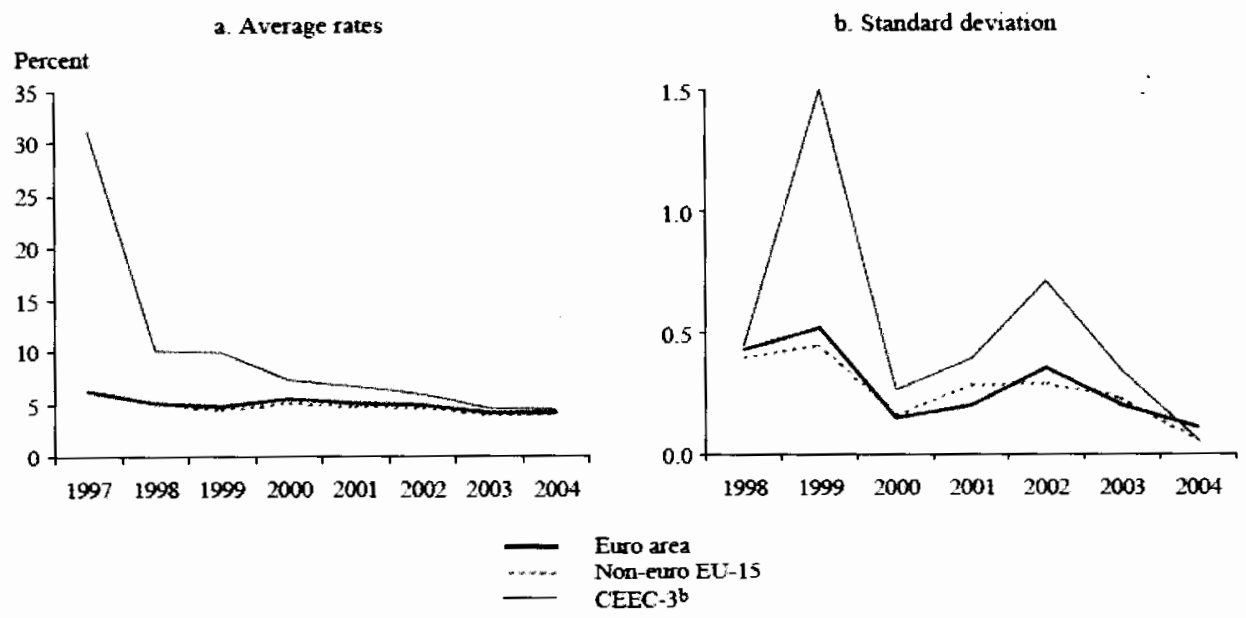

a Annual long-term interest rates are represented by the yield on 10-year government bonds. - b Due to data availability of 10 year government bonds, CEEC-3 is the average of Bulgaria, Czech Republic, and Slovakia. 
The following analysis and the four graphs below focus on the public deficit /GDP ratio of EU 25, the gross domestic debt/ GDP ratio of EU-25, the gross domestic debt/ GDP ratio trend of EU-15 and EU-25, and the prospect debt development in the euro area..

\section{Graph 2: Public deficit as a percentage of GDP for EU-25}

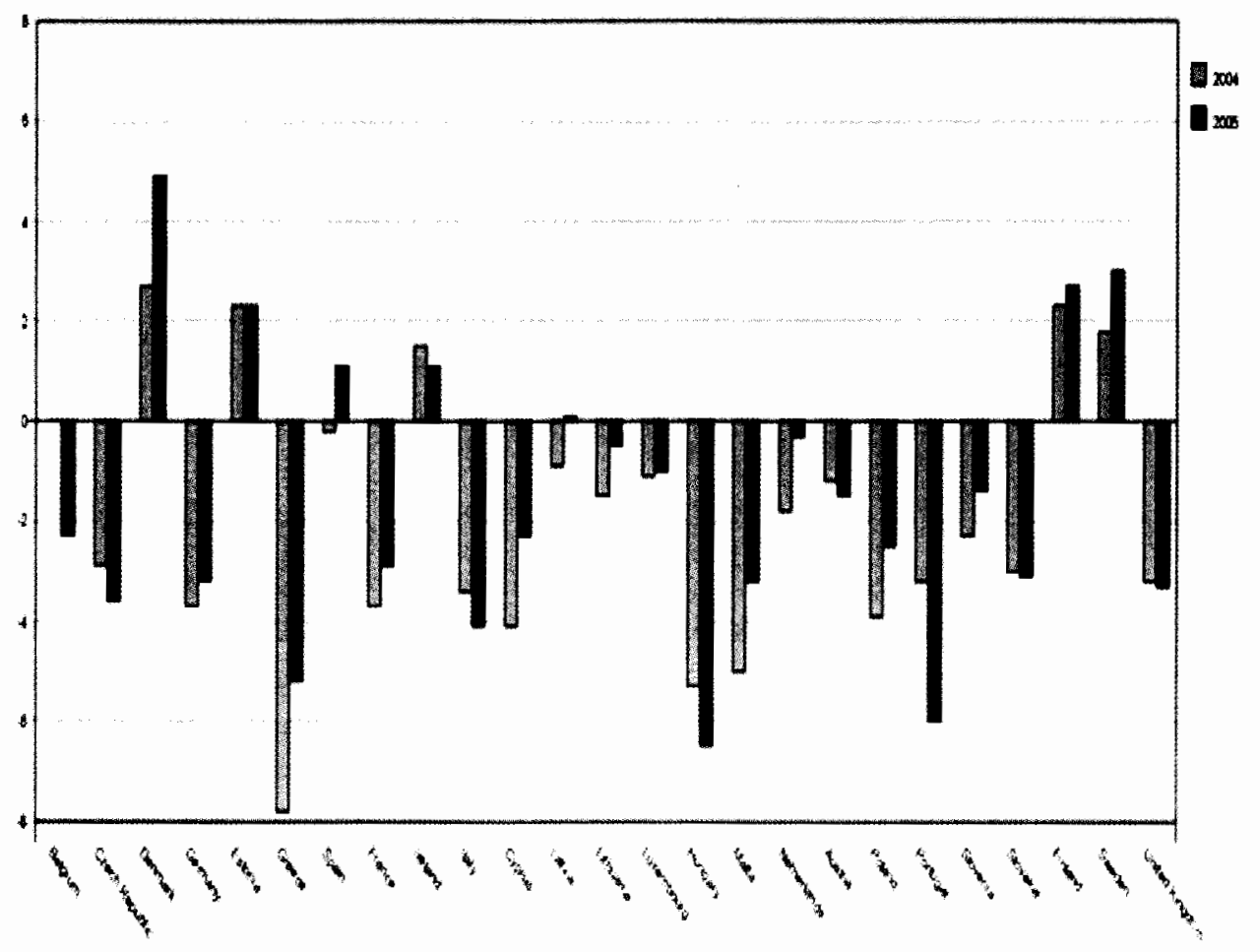

Source: Eurostat, own graph

Graph 2 illustrates that Germany, Italy, Greece, Portugal and France as EMU members quite substantially exceed the maximum $3 \%$ budget deficit threshold. European economy is in recovery and in such normal times SGP targets $0 \%$ budget deficit, so that EMU members will be able to use the budget deficit instrument in times of idiosyncratic economic disturbances. Among the new EU members, Malta, Hungary, and Czech Republic have budget deficits of more than $3 \%$ as of end of 2005 . 
Graph 3: General Government Debt as a percentage of GDP for EU-25

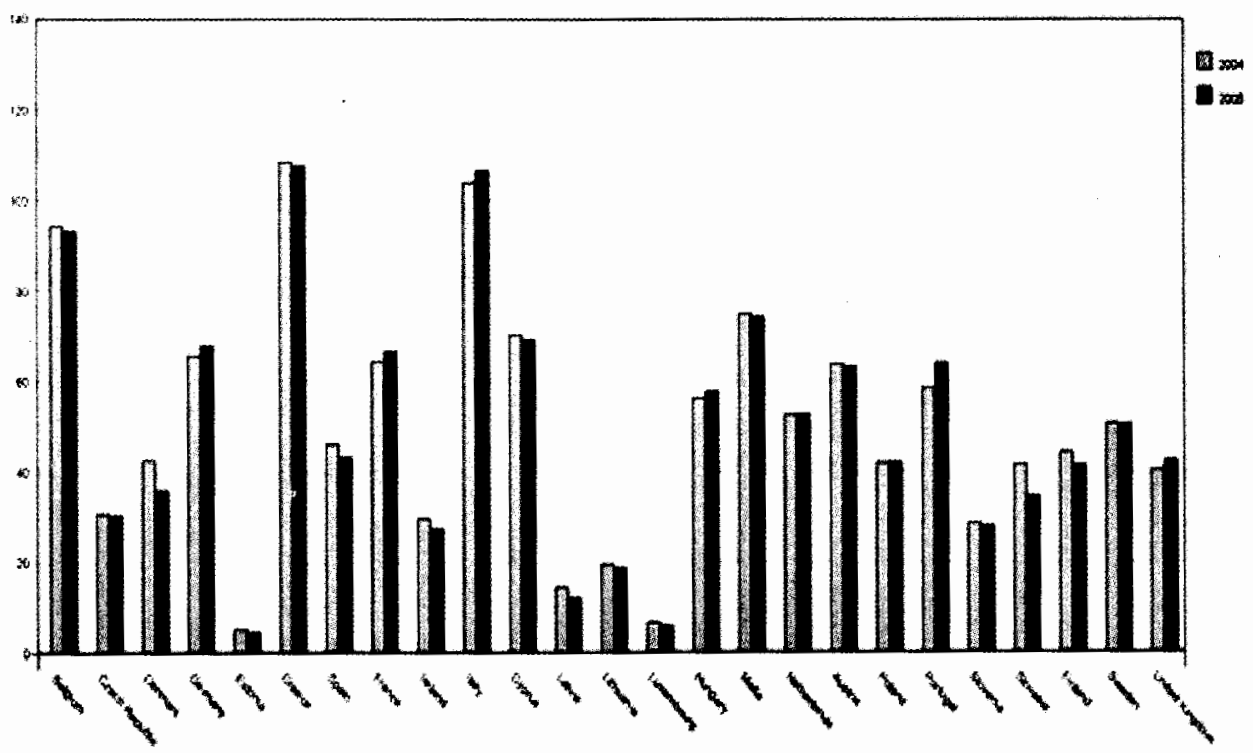

Source: Eurostat, own graph

Graph 3 demonstrates that among EMU members Belgium, Germany, Greece, France, Italy, Austria and Portugal have breached the $60 \%$ gross debt/GDP threshold. Among the new EU members, Cyprus, and Malta have over $60 \%$ gross debt/GDP ratios and Hungary is at the threshold.

Graph 4: Average Debt/ GDP ratio of EU-15 and EU-25

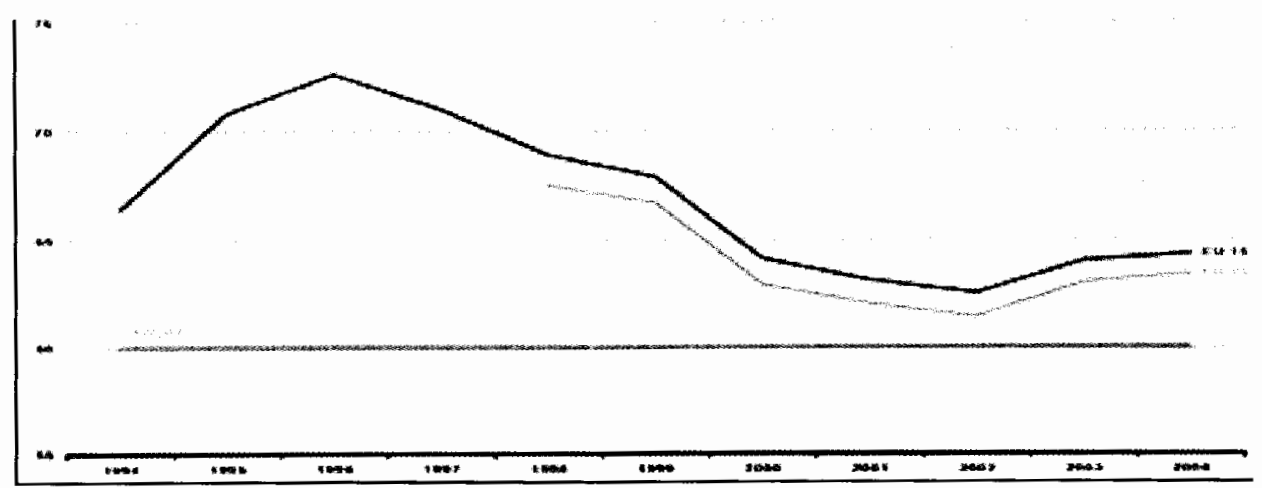

Source: Eurostat 
Graph 4 shows the increasing trend for the average debt/GDP ratio of EU15 which is higher than EU 25, despite the fact that in EU-15, the 3 non EMU members have ratios below $60 \%$.

Graph 5: Debt development in the euro area, with and w/o medium term consolidation

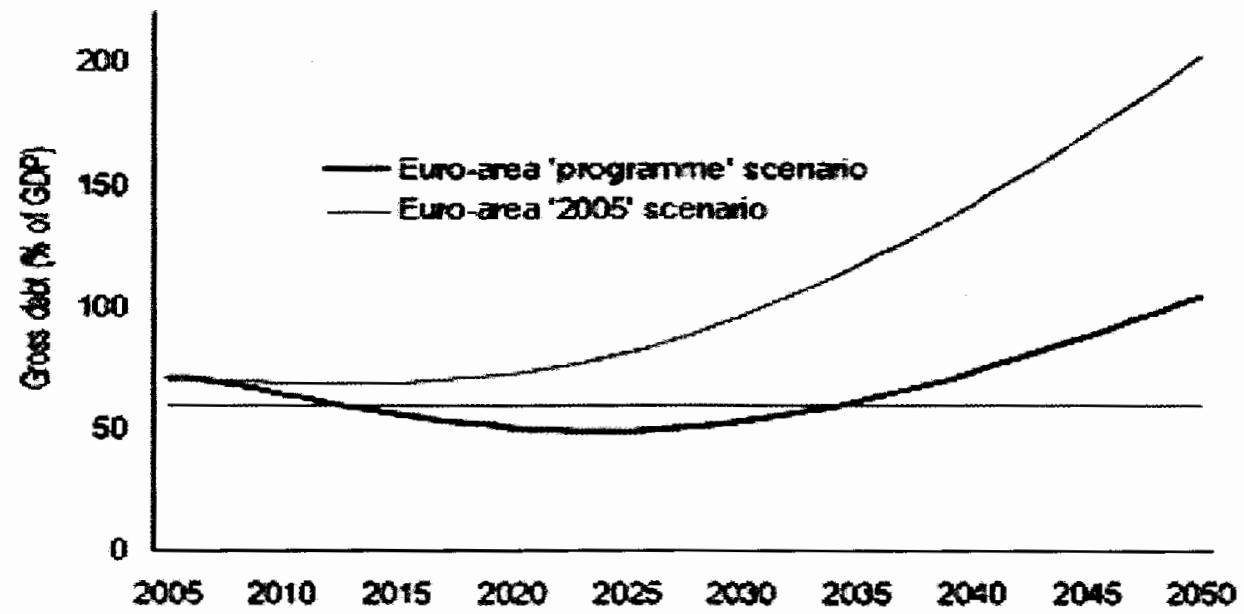

Source: E.C., (2006)

Graph 5 demonstrates the inevitable increase of the gross debt / GDP ratio of the present EMU. The euro-area debt will increase sharply during the coming decades due mainly to future higher expenditures on pensions and health care of the ageing population. (E.C., 2006:18) The graph shows the increase of gross debt to GDP ratio to the levels of $200 \%$ in 2050 unless necessary precautions by member states to attain their medium term objectives (MTO) defined by the revised SGP are not taken.

The graphs clearly show that many of the present and prospect EMU members have problems with their budget deficits and gross debts and that they have to take precautions. The graphs also demonstrate the huge differences between countries in budget deficit/surpluses and gross domestic debt/GDP ratios. The sovereignty over fiscal policies is at the discretion of EU members. The power of the European Authorities on the fiscal front is around $1 \%$ of EU GDP. Being forced to make changes in spending and/or taxes in order to solve these problems as an individual EMU member may also create large idiosyncratic asymmetric shocks.(De Grauwe, 2003:29) 


\subsection{Real Convergence}

For EMU membership, real convergence is not a formal prerequisite. ${ }^{12}$ Real convergence can be defined as convergence of productivity levels, real per capita income, structures of production and employment, quality of regulatory and supervisory institutions.

The $\sigma^{-}$(sigma) convergence measures the dispersion of per capita income or productivity among different economies over time and implies that wealth differences and asymmetries are diminishing among a group of economy over time. The following graph shows the values of $\sigma$ convergence of GDP per capita (GDPpc), GDP per worker (GDPpw), investment share (GFCF/GDP), employment ratio (as percentage of population) (Emp/Pop) and unemployment rate (Unemp.) for the period 1970-2001.

\section{Graph 6: Sigma convergence by variable (1970-2001)}

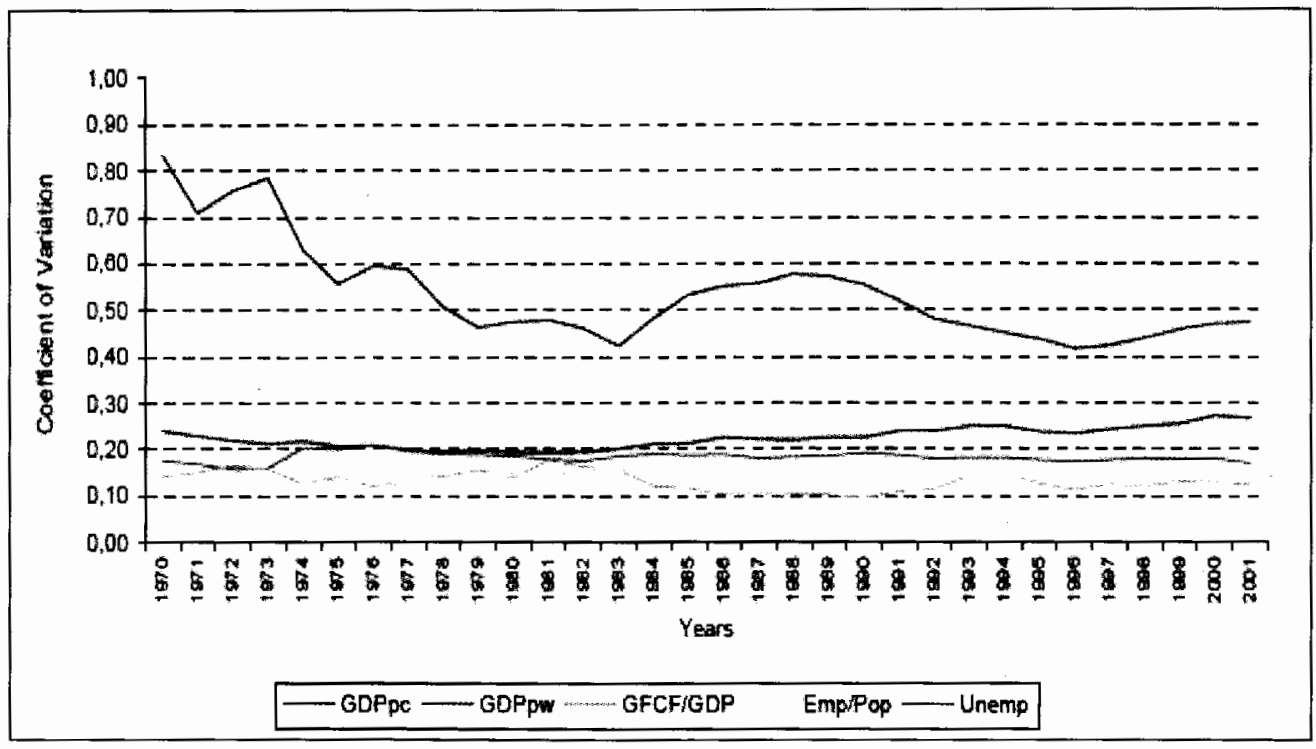

Source: Soukiazis and Castro, (2005)

12 "Apart from nominal convergence there is also real convergence, defined as a catching-up in economic development, measured by the level of GDP per capita, or sometimes as economic reforms, institutional and structural changes needed for the catching-up process. Real convergence is not a formal precondition for joining the euro area, although certain level of achieved real convergence is welcome or expected." (Lavrac, 2004:1) 
As can be seen from graph 6, it is hard to evidence real convergence for unemployment and GDP per capita in EU-15 despite the concentrated efforts, at least, since early 1990s. The data shows that the difference is huge for unemployment and then for GDP/head whereas investment and employment ratios show the smallest differences. As the graph shows, the differences in GDP per head declines smoothly from 1970 to 1983, but then the inequalities in living standards increase. This shows that after Maastricht, despite co-ordination of economic policies and single market and the creation of the monetary union, the cohesion has not realised. (Soukiazis and Castro,2005) Graph 7 shows the differences in price levels and GDP/capita of the prospect EMU members.

\section{Graph 7: Differences in price levels and GDP per capita (as percent of} EU-15)

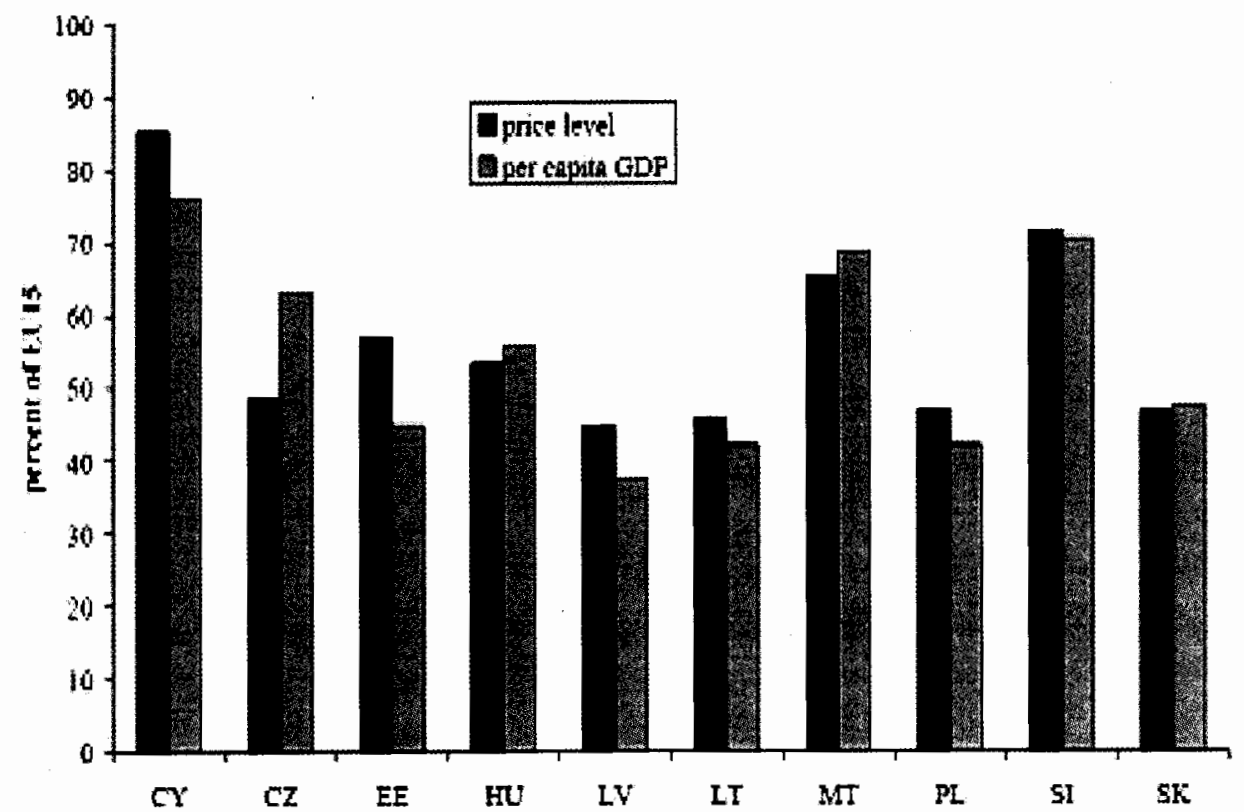

Source: De Grauwe and Schnabl (2005).

The new EU members have a long way to go, with the GDP per capita of Latvia, for example, below $40 \%$ of the EU-15 average. Besides, due to the Balassa Samuelson effect during the catching-up process with high productivity growth, these countries will have to cope with the dilemma of real versus nominal convergence. (De Grauwe and Schnabl, 2005:545) 
In terms of sectoral composition of production, Lithuania is an exception with a large share of agricultural employment. (Buiter and Siebert, 2006:5) In terms of institutional reforms, there is still way to go with high concentration in the banking sector, not completely developed structure of bank products, non-existence of collateralized debt market and poorly functioning venture capital market. There is also high bad debt problem in some new EU members, notably in Poland and Malta.( Fritz et al., 2004:785-787)

For the present EMU members, the following graph shows the average annual growth rates of Euro zone in comparison with US data.

\section{Graph 8: Average annual real growth rates 1999-2005}

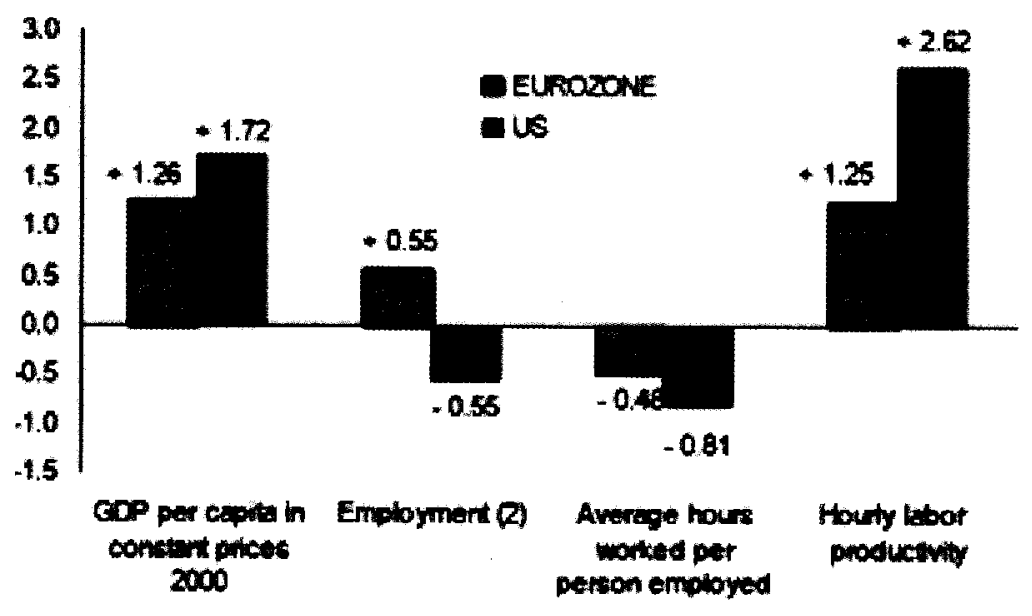

Source: E.C., (2006)

The performance of Euro economy compared to US and even to the other EU members who opted out started to be a concern. The reason behind the almost stagnating GDP, which is visible from the preceding graph is due mainly to rigid labor markets, sticky wages and prices, the fiscal tightening of SGP and the low-leveled price stability policy of ECB. The periphery is gaining momentum whereas the old core (Germany, Italy, and France) is struggling to grow. (Hishow, 2006: 1-15) The twice as much hourly labor productivity of US, compared to EMU is also striking. 


\subsection{The OCA Criteria}

According to the OCA Theory, the possibility of asymmetric shocks in a monetary union can be mitigated by the increase in economic integration and flexibility.

\subsubsection{Economic Integration}

Graph 9 shows the evolution of trade integration of goods for EU -15 fom 1995 to $2004 .^{13}$

\section{Graph 9: Evolution of trade integration in goods (EU 15)}

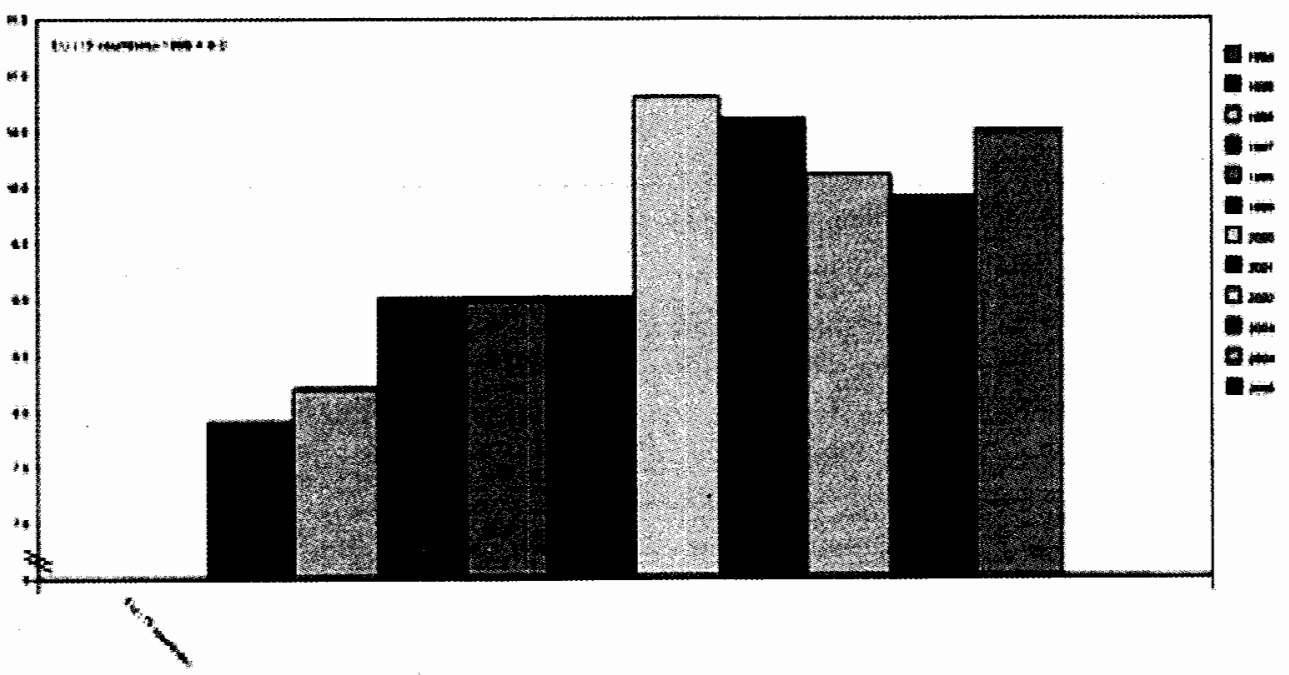

Source: Eurostat

The overall trade integration of goods in EU 15 has jumped from 9\%, which was prevailing during the 1997-1999 period, to the level of almost $11 \%$ in 2000 . However, as graph 9 demonstrates, the trade integration of goods in 2000 could not be attained during the following 4 years until the end of 2004. "At least, the de facto introduction of monetary union by fixing exchange rates in 1999 did not prevent intra -EMU trade from falling."(Gern, et al, 2004:4)

13 The trade integration of goods is measured as the average value of imports and exports of goods of countries per their GDPs. 
Graph 10 illustrates the breakdown of trade integration in goods of EU 25 plus the candidate countries for the years 2004 and 2005.

\section{Graph 10:Breakdown of trade integration in goods (EU 25+candidates)}

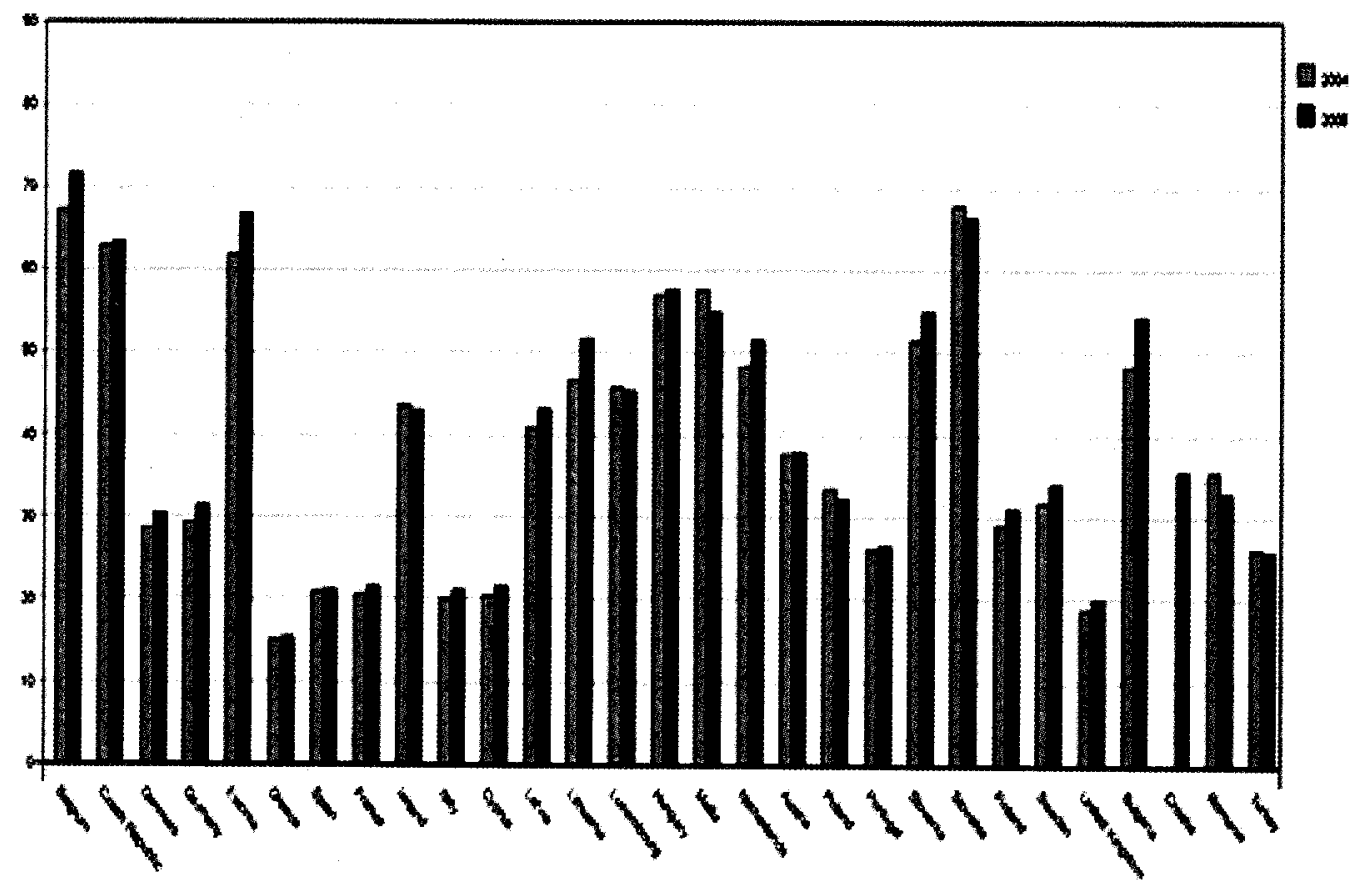

Source: Eurostat

The preceding graph shows clearly that all EMU candidates except Cyprus perform much better in trade integration of goods when compared with the southern members of EMU, namely Greece, Spain, France, Italy and Portugal. This ensures the relatively low level of problems the existing EMU members and the euro zone will be prone with the enlargement. The trade integration of goods of Belgium, Ireland and Luxemburg are almost twice as high as the northern countries of Denmark, Sweden, Finland and even Germany. The very low level of U.K trade integration with EU shows one important reason behind U.K's hesitation to join EMU.

\subsubsection{Flexibility}

Flexibility refers to flexibility of labor markets in terms of mobility of labor and flexibility of wages.Approximately $1.5 \%$ of EU-25 citizens live and work in a different Member State from their country of origin - a proportion that has hardly changed for the last 30 years. (EU Official Site, Employment and Social Affairs) 
In EU, the employment protection legislation is very rigid. In terms of wages, the rigidity in EMU is already a known fact. "It appears premature to expect any significant changes to the responsiveness of wages to economic developments in the euro area". (E.C., 2006:32) The few measures adopted in employment protection targeted flexibility of work contracts mainly for new entrants and this left the legislation unchanged on permanent employment and it may act as a barrier to labor market adjustment. (E.C., 2006:31)

Graph 11, shows the labor market rigidities for the prospect EMU members in comparison to Portugal (the EMU-12 max), Ireland (the EMU12 min.), EMU-12 mean, sample 85 countries, US and UK. The graph illustrates that EMU 12 mean is still higher than the mean of 85 sample countries. The minimum rigidity level in EMU is seen in Ireland and it is still higher than that of both US and UK. The graph also demonstrates that the labor markets of the prospect EMU members are as rigid as those of EMU members. This shows the lack of flexibility also in the enlarging EMU. What's more, the EMU candidates have a transition period for the mobility of labor.

\section{Graph 11: Indices of labor market rigidity}

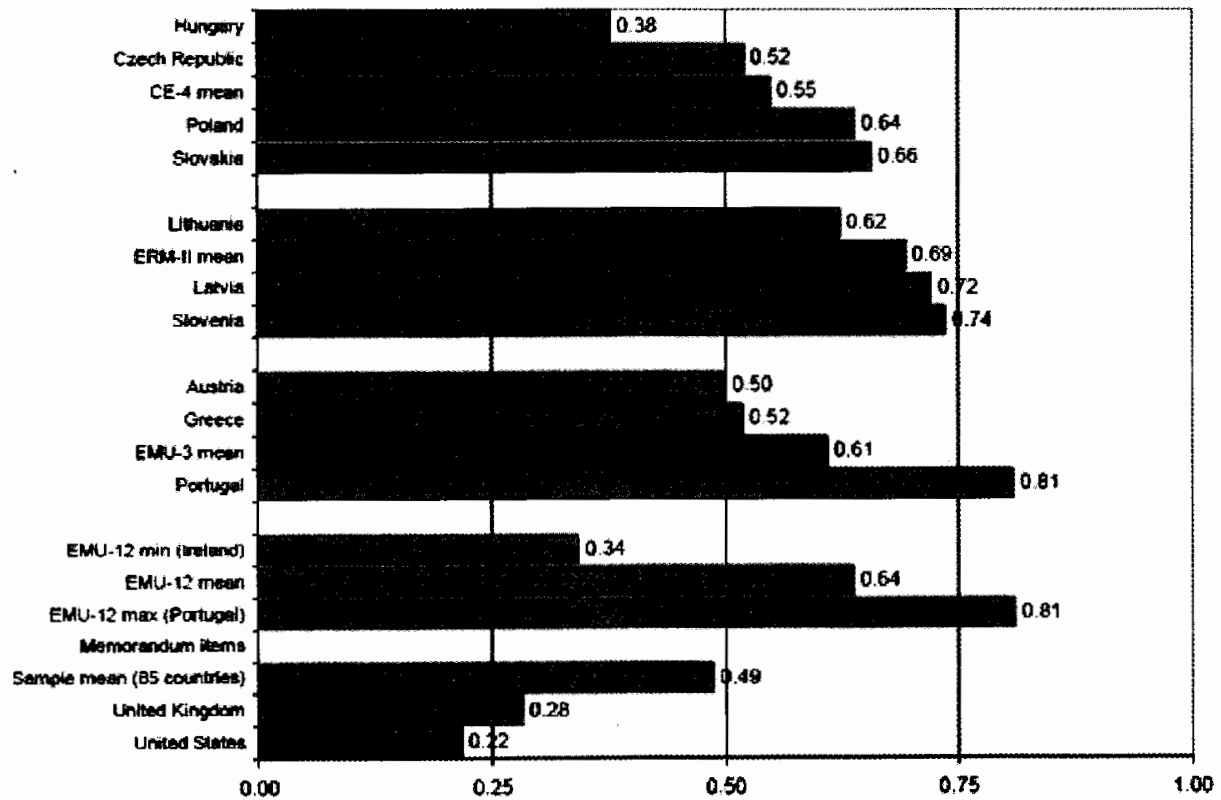

Source: Babetskii (2006) 
The analysis so far carried shows that the OCA principles that were not required to join the EMU led to the wrong country composition. Spain, Portugal, Italy and Greece, the periphery has relatively low intra-industry trade, compared to the others. The very same countries rank in the very first rows for rigidity in labor market. This is one of the main reasons behind the existing disparities between the core and periphery in EMU. In the absence of any mechanism for asymmetric shocks, in terms of monetary sovereignty and flexibility, the symmetry of cycles become crucial for the sustainability of EMU.

\subsubsection{Symmetry}

A high degree of symmetry between business cycles may reduce the probability of asymmetric shock and the non alignment of the business cycle may result in an asymmetric transmission of monetary policy actions of the ECB. (Altavilla, 2004:870 for de Grauwe) The cycles of output gaps in euro area is demonstrated in graphs 12 and 13, and the dispersion in annual growth in graph 14.

The cycles seem to be aligned for a number of large countries in the euro area. However, it is not possible to talk about the alignment of cycles for the euro area.

\section{Graph 12: Output Gaps in the Euro-large}

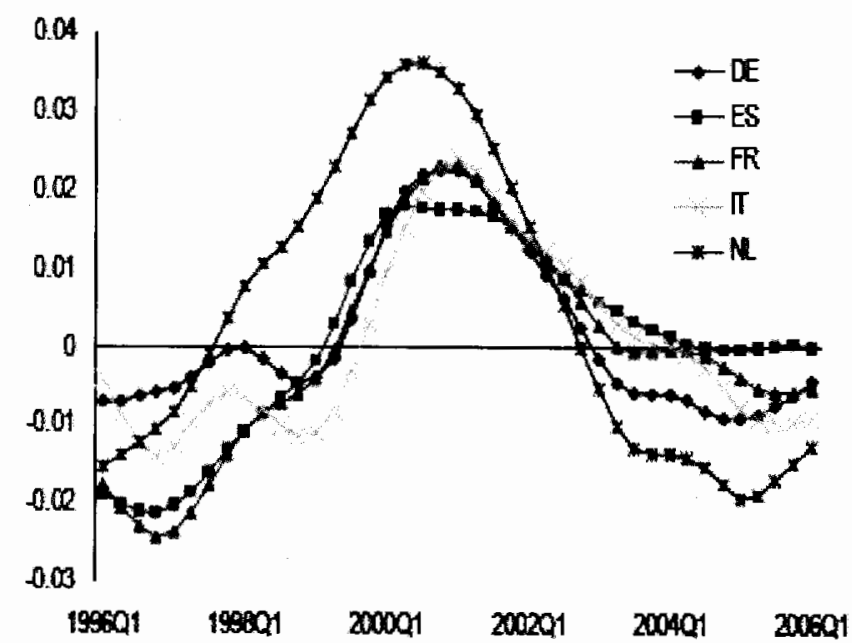

Source: E.C., (2006) 


\section{Graph 13: Output Gaps in the Euro-small}

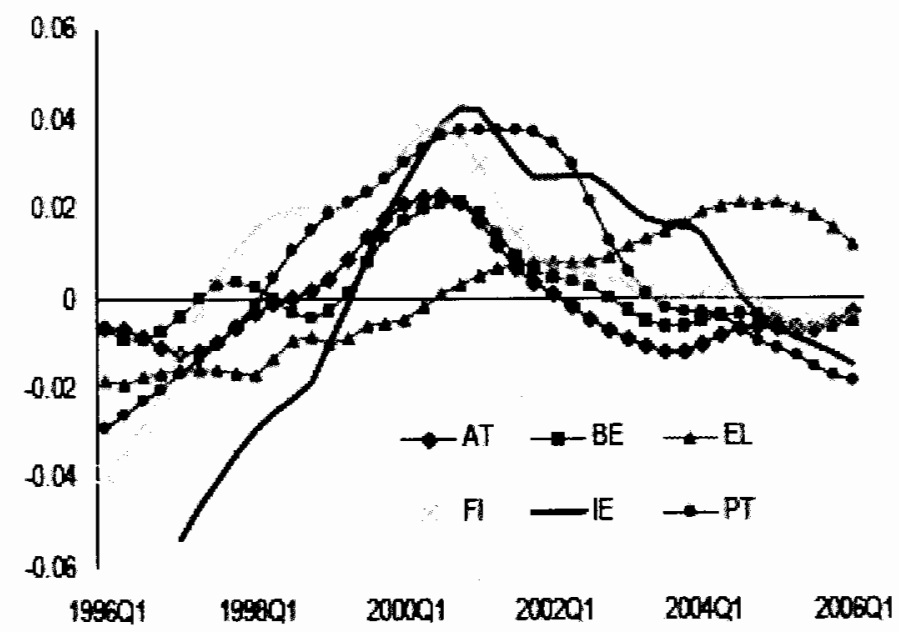

Source: E.C., (2006)

The persistent euro area growth differences, in graph 14 below, of Euro4, Euro-10 and Euro-12 show the slow growth in France, Italy, Spain and Germany diverging quite substantially from the euro zone. Growth dispersion, in the following graph, measures the average percentage deviation of EMU members from the statistical mean of the euro zone.

\section{Graph 14: Dispersion in annual growth in the EMU.}

(Standard deviation in \%-1980-2005)

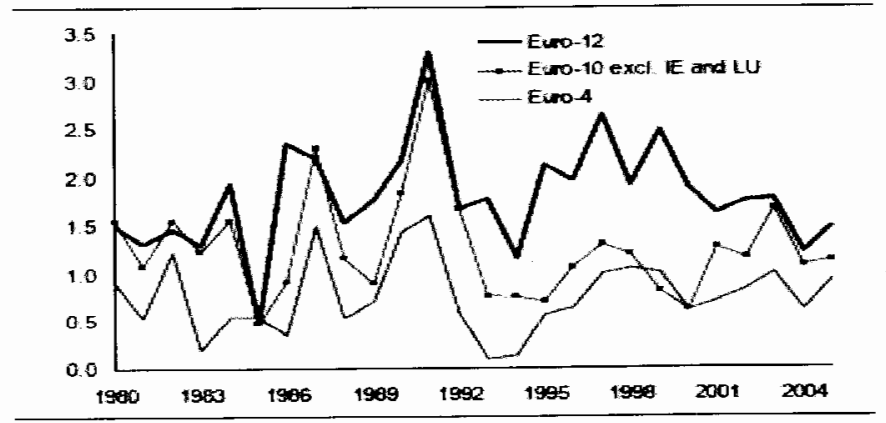

(1) Euro 12: all exro NIS: Eruro 10: all exuo Mfember States excluding IF and LU: Euro 4: DE. FR MT, ES.

Source: E.C., (2006)

The dispersion in annual growth stems mainly from the loss of competitiveness of the slow growing countries. Intra EMU competitiveness is illustrated in graph 15. 


\section{Graph 15: Developments in intra-area competitiveness}

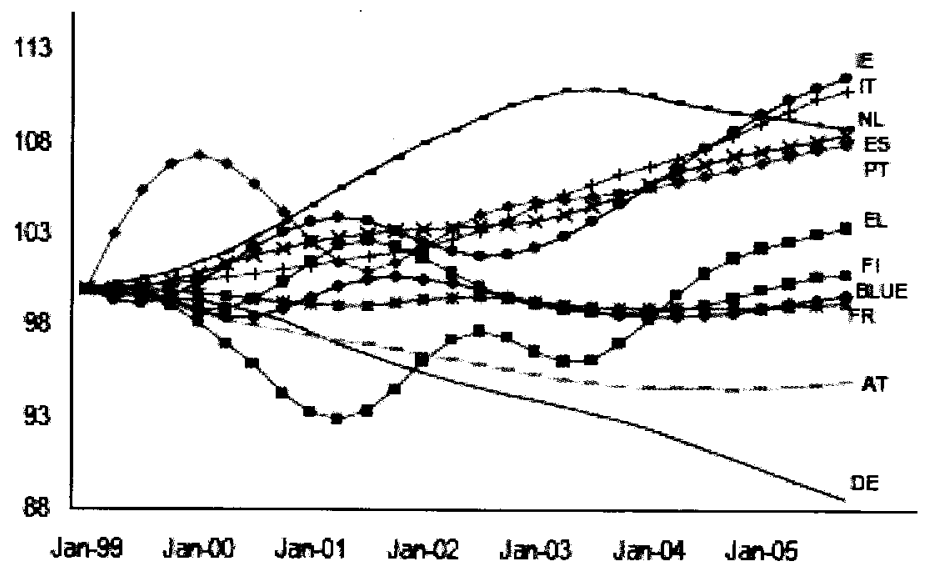

Source: E.C., (2006)

The real effective exchange rates in the intra-euro area show that some countries have lost competitiveness The developments in intra-area competitiveness is actually counter to the idea that the OCA process is endogenous. (Christl, 2006:12) The countries like Spain and Italy lost their competitiveness in exports. More open and small countries like Belgium and Austria which do not have competitiveness problems undertake structural reforms.(Christl, 2006:15) Competitiveness can be restored by lower rates of price and wage inflation than the euro zone, which seems quite impossible due to the tight $2 \%$ target of ECB. The restoration of competitiveness seems to be resolved at the cost of unemployment and output.(De Grauwe, 2006a:7)

The analysis so far carried also show that no mechanism could be developed to symmetrically absorb exogenous shocks in terms of flexibility and integration.

Regarding the sustainability of the enlarged EMU, many economists underline the fact that the economic potential of the new EU member states is marginal as it represents only 6\% of the EMU GDP and diverging developments would not be visible in euro area aggregates. ${ }^{14}$ However, the asymmetric shocks will surely be felt deeply in these countries. Also

${ }^{14}$ See Fritz et al., 2004, Gern, et al., 2004 among others. 
"in an enlarged EMU the ECB board will lose its strategic position which ensures so far that interest rates decisions mirror the need of the whole Euro land as such and possible coalitions of small countries could emerge, imposing Taylor rule interest rates tailored for conditions prevailing only in a limited part of the euro system". (Prausello, 2004:15 for the quotation of de Grauwe)

\section{Asymmetric Shocks vs. Endogeneity}

The empirical evidence for co-movement and business cycle asymmetries may give a better idea about the path of EMU, more towards endogeneity or asymmetry of shocks.

\subsection{Literature Review of Empirical Evidence for Asymmetric Shocks}

The empirical evidence shows the possibility of asymmetric shocks in the euro zone. Bayoumi and Eichengreen was one of the first who estimated the synchronization of business cycles for potential EMU members in 1992. They found that aggregate supply disturbances were considerably less correlated across European countries. They could distinguish a 'European core' made up of France, Germany, Luxembourg, the Netherlands, Belgium, and Denmark, from a 'European periphery' composed of the U.K, Greece, Ireland, Italy, Spain and Portugal. They also found out that the correlation of shocks was highest among the members of the core and claimed that a monetary union made up of the core would function as smoothly as the US currency union. (Eichengreen, 2002)

The result of the empirical work of Ballabriga et al. in1999 who investigated nominal and real disturbances in four EU countries show that in the short run asymmetric shocks are dominant. (Prausello, 2004)

The results of the cluster analysis to a data set constructed to reflect OCA criteria shows that the core EMU group revolving around Germany comprises France, Belgium, Austria and Netherlands, indicating a high business cycle correlation with Germany. There is a Northern group composed of Nordic countries plus UK and Ireland and a Southern group of Italy, Spain, Portugal, and Greece. The author asserts,

"... a one-size-fits-all' monetary policy will be inappropriate to certain member countries and could threaten the union's 
sustainability. A key issue here, which this analysis can not comment upon, is how far this problem will prove transitory (as the endogeneity literature suggests) or, on the other hand, persistent." (Artis and Zhang 2001:54)

The results of econometric study of Korhonen and Fidrmuc in 2001 on the correlation of demand and supply shocks of countries with Euro area are presented in figure 6 below.

\section{Figure 6 : Correlation of Demand and Supply Shocks with Euro area}

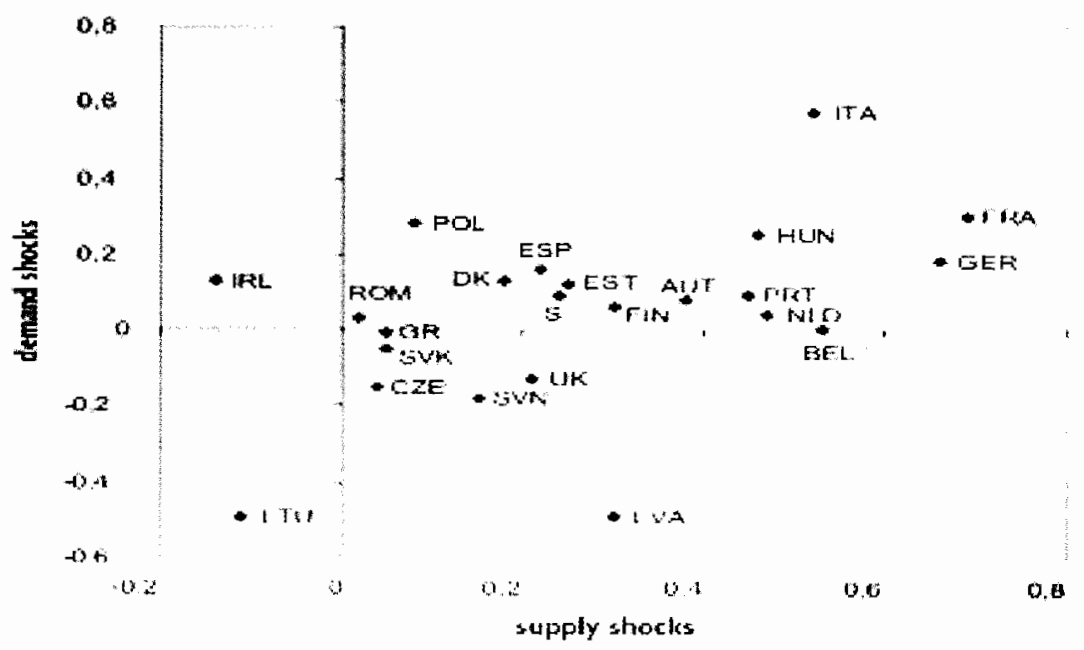

Source: De Grauwe (2002)

The figure shows high correlations between large countries (Germany, France, and Italy) with the euro area. The figure also shows much less of correlation for the Central European (CE) countries, with the exception of Hungary and Estonia. The low correlation of these countries supply shocks with the Euro area is not assumed to disappear in the monetary union. (De Grauwe, 2002)

Fountas and Papagapitos empirically tested the monetary transmission mechanism for EMU. The evidence shows that the external finance premium is an important leading indicator of real economic activity in Germany and Italy but not in France. ${ }^{15}$ They concluded that the heterogeneous credit channel might imply that the ECB monetary policy is

\footnotetext{
${ }^{15}$ The predictive ability of the interest rate spread between private and government securities for fluctuations in real output is used as an indirect evidence for the existence of the credit channel
} 
transmitted in different ways across EMU members. (Fountas, and Papagapitos, 2001)

Hence, the econometric evidence also suggests that there is not a high level of symmetry in the euro area, which would reduce the probability of asymmetric shocks. Instead, the lack of alignment of the business cycles in EMU may result in an asymmetric transmission of monetary policy actions of the ECB. A looser monetary policy today may be perfect for Germany but may create problems for Spain.(Hishow, 2006:14)

The empirical works in the literature for the similarity of shocks and cycles using co-integration method include the study of Alesina et al, dated 2002, where co-movements of prices and outputs are used as a test of optimality of a currency union, also found the lack of co-movement

Prausello in 2003 used the money stocks M and GDP values in his cointegration test, where he also included the two considerably big new EU members Poland and Hungary and used Germany as the core country. The results of the co-integration test suggest a possible evidence of progressive enhancing of economic links only between Germany and Hungary-Poland. (Prausello, 2004:20)

The empirical evidence also shows the lack of long term co-movements of nominal convergence criteria of EMU. The co-integration tests try to find out the co-movement in the long run behavior of the indicators analyzed. Haug, A et al. conducted a co-integration analysis for all the Maastricht nominal convergence criteria for the 12 EMU members in 1999. (Haug et al., 1999)

The results of their research demonstrate that not all the EU countries of the euro zone could form a successful EMU over time. Another similar study for co-integration of Maastricht criteria is conducted by I.S Meister in 2002 (Meister, 2002). The findings of Meister's paper indicate that certain degree of convergence is existing for some of the Maastricht criteria between EMU-12 but the prospect EMU members lag further behind.

Kutan and Yiğit, in 2004, used panel unit root techniques and took both Germany and Greece as benchmark for their econometric search of nominal convergence for the prospect EMU members. Their results for nominal convergence indicate that Estonia, Latvia and Lithuania, the Baltic States that pursued hard pegged exchange rate regimes exhibit the strongest monetary policy and price level convergence. Poland and Slovak Republic exhibit some nominal convergence, whereas Cyprus and Malta show only CPI convergence. No nominal convergence is evidenced for Czech 
Republic, Hungary and Slovenia. To continue the use of flexible exchange rates and to pursue fiscal sustainability is suggested as to be better choices for these three rather than rushing for EMU membership.(Kutan and Yiğit, 2004)

\subsection{Empirical Analysis of Co-integration}

A Co-integration analysis is conducted for long term interest rates, where convergence to Maastricht criteria is considered as perfect. The long term bonds of Germany are used as benchmark. The analysis tries to find out the level of co-movement, the symmetry of business cycles, between long term interest rates of euro area, 7 years after the launch of EMU.

\subsubsection{Dataset}

Eurostat database is used for the long term interest rates of EMU-12. The bond rates are 10 year government bond rate average yields of the secondary market. This dataset is named 'Maastricht Criteria' by Eurostat and it is the real dataset used for the compliance of long term interest rate criteria of Maastricht. The time series is for the period between January 1995 and December 2005.

\subsubsection{Methodology}

If two or more non-stationary time series combined linearly are stationary, the time series are considered as co-integrated. Hence, first, unit root tests will be applied to the time series in order to see if the time series are non-stationary. If the time series, at their level or first difference, are non- stationary, then unit root tests for stationary of pairwise residuals will be carried. The logic is that if $\mathrm{X}_{\mathrm{t}}$ and $\mathrm{Y}_{\mathrm{t}}$ are non-stationary time series, then the usual regression equation can be rearranged as: $u_{t}=Y_{t}-\beta_{1}-\beta_{2} X_{t}$

Now $u_{t}$ is a linear combination of $X_{t}$ and $Y_{t}$ and if it is stationary, then as the trends in $X_{t}$ and $Y_{t}$ cancel out, $X_{t}$ and $Y_{t}$ are co-integrated. The last step is to apply the Johansen co-integration test. The Johansen co-integration test will enable us to double check the existance of co-integration.

\subsubsection{Unit Root Tests}

To test for co-integration, non-stationary time series, time series without unit roots- are needed. Thus, first an Augmented Dickey Fuller (ADF) unit root test for non-stationary is executed for EMU-12. ADF test results are compared with Mc Kinnon Critical Values. The ADF tests are carried 
without a trend, with an intercept and lag length is chosen as $3 .{ }^{16}$ All the time series are found to have a unit root in their levels. Thus, a unit root test on the first differences is executed. Again the ADF tests are carried out without a trend, with an intercept and lag length is chosen as $2 .{ }^{17}$ The unit root test on the first differences is found to reject the null hypothesis of a unit root at $1 \%$ significance level. The results show that they are all I (1).

Table 1: ADF Unit root test for non-stationarity

\begin{tabular}{|l|l|l|}
\hline SERIES & LEVELS & FIRST DIFFERENCES \\
\hline GER & -1.409679 & $-4.813580^{* * *}$ \\
\hline AUS & -1.370065 & $-4.431930^{* * *}$ \\
\hline BEL & -1.540403 & $-4.417331^{* * *}$ \\
\hline FIN & -1.620780 & $-4.563172^{* * *}$ \\
\hline FRA & -1.527047 & $-4.612245^{* * *}$ \\
\hline GRE & -1.761898 & $-5.969325^{* * *}$ \\
\hline IRE & -1.490034 & $-4.345023^{* * *}$ \\
\hline ITA & -2.157551 & $-4.195606^{* * *}$ \\
\hline LUX & -1.809584 & $-4.849429^{* * *}$ \\
\hline NED & -2.326212 & $-4.717847^{* * *}$ \\
\hline POR & -1.352056 & $-4.253162^{* * *}$ \\
\hline SPA & -2.065773 & $-4.210916^{* * *}$ \\
\hline
\end{tabular}

GER: Log of German Interest rates. Mc Kinnon Critical Values are used.

Note: * denotes rejection of the hypothesis at $10 \%$ significance level, ** at $5 \%$ and *** at $1 \%$.

${ }^{16}$ For the ADF tests at level and first difference, the appropriate lag length is chosen with the help of Akaike's criterion.

${ }^{17}$ Source for the tables 2-5 is own estimates. 
Then an ADF unit root test for stationarity of residuals for pair-wise EMU-12 is conducted. This time ADF test results are compared with the Engle Granger Critical Values.

Table 2: ADF Unit root test for Stationarity of Residuals

\begin{tabular}{|l|l|}
\hline SERIES & LEVEL \\
\hline GER-AUS & -1.932481 \\
\hline GER-BEL & -2.790143 \\
\hline GER-FIN & $-3.483733^{* *}$ \\
\hline GER-FRA & $-3.134699^{*}$ \\
\hline GER-GRE & -2.011843 \\
\hline GER-IRE & -2.850343 \\
\hline GER-ITA & -2.147922 \\
\hline GER-LUX & $-3.682945^{* *}$ \\
\hline GER-NED & -1.594081 \\
\hline GER-POR & -2.747558 \\
\hline GER-SPA & -2.483924 \\
\hline
\end{tabular}

GER: Residuals of log of German - France Interest rates. Engle-Granger Critical Values are used.

Note: * denotes rejection of the hypothesis at $10 \%$ significance level, $* *$ at $5 \%$ and $* * *$ at $1 \%$, with intercept and no trend

\subsubsection{Johansen Co-integration Test}

As the time series are found to be non-stationary, the Johansen cointegration test will be carried to double check if the non-stationary time series are co-integrated. The Johansen co-integration test is conducted without a trend, with an intercept and lag length is chosen as $3 .^{18}$

${ }^{18}$ The appropriate lag length is chosen with the help of Schwartz criterion 
Table 3: Johansen Co-integration Test (for LONG TERM COINTEGRATION)

\begin{tabular}{|l|l|l|l|l|l|}
\hline SERIES & EIGENV. & $\begin{array}{l}\text { LIKL } \\
\text { H.R }\end{array}$ & $\begin{array}{l}\text { 5\% } \\
\text { C.V }\end{array}$ & HYPO.C.E & C.E \\
\hline GER-FIN & 0.132026 & 23.06020 & 15.41 & None & 1 \\
& 0.039194 & 5.077765 & 3.76 & At most 1 & \\
\hline GER-LUX & 0.107039 & 16.43867 & 15.41 & None & 1 \\
& 0.016095 & 2.060708 & 3.76 & At most 1 & \\
\hline
\end{tabular}

Among EMU 12, at 5\% significance level, there is long term cointegration only between Germany - Luxembourg and Germany-Finland.

\subsubsection{The Results of Co-integrationTest}

The econometric analysis carried out illustrates that there is comovement of long term interest rates between Germany-Luxembourg and Germany-Finland at 5\% significance level and Germany-France at only $10 \%$ significance level. Thus, the majority of the EMU members do not have symmetry of business cycles in long term interest rates with Germany. The endogeneity of OCA criteria apparently has not realised ex-post for the symmetry in the business cycles of the long term interest rates in the euro area, during the past 7 years.

\subsection{Endogeneity of OCA Criteria}

The proponents of Endogeneity of OCA criteria claim that over time they will evolve toward more symmetric shocks, more flexible wages, more mobile labor, more fiscal flexibility but that by leading to more trade, euro will lead to more business cycle conformance should not be overstated, especially in the short run. (Eichengreen, 2002) Frankel, the father of endogeneity with Rose, claims in 2002, that the sustainability of EMU will depend on whether Europe will experience a large asymmetric shock within the next few decades. If not, only then, the endogenity of OCA criteria will have been realized during the next few decades with the strong enough trade links and a seriously disruptive asymmetric shock will thenceforth be unlikely. (Frankel, 2002) De Grauwe suggests the realization of a system of fiscal transfer with a centralized union budget which provides some insurance against asymmetric shocks, and a central European government with the power to spend and tax. (De Grauwe, 2006a:11-19). 
"...a political unification is needed to reduce the scope for the emergence of asymmetric shocks and to embed the Euro zone in a wider system of strong political ties that are needed to take care of the inevitable divergent economic movements within the Euro zone....In the long run, however, there can be little doubt: without further steps towards political union the Euro zone has little chance of survival" (De Grauwe, 2006b:23)

\section{Conclusions}

EMU is not an OCA. It is composed of a core and a periphery, with differences in openness to trade, asymmetries in business cycles and a union level lack of flexibility of labor markets. The non-existence of symmetry in the business cycles of EMU is also confirmed with the co-integration analysis. The euro area is prone to asymmetric shocks and the asymmetric transmission of the monetary policy, without any tool to counterbalance the asymmetries.Thus, in the euro zone, precautions should be taken for possible asymmetric shocks in terms of a sufficient federal budget and a system for fiscal transfers. The EMU enlargement will aggravate the problem. OCA criteria, some of which are not present ex-ante in the EMU candidates, are deeply believed to realize ex-post. The sole condition of fulfillment of Maastricht criteria is not sufficient for the success of each new EMU member. The way to handle the country specific problems in the enlarged euro zone will be even harder with the one-size-fits all monetary policy of ECB. The asymmetric shocks or the asymmetric transmission of the monetary policy in the new members may not even be felt in EMU, but will deeply be suffered in the new euro area participants. Therefore, for the sustainability of the enlarging euro area, the new EU member states have to evaluate their economies also in terms of real convergence and OCA criteria and should be more cautious in their rush to EMU. 


\section{References:}

Altavilla, C. (2004). 'Do EMU Members Share the Same Business Cycle?' Journal of Common Market Studies, 42(5), pp. 869-896(28).

Artis, M and Zwang, W. (2001). 'Core and Periphery in EMU: A Cluster Analysis', Economic Issues, 6 (2).

Babetskii, I. (2006). 'Aggregate Wage Flexibility in Selected New EU Member States'. Working Paper Series No:1 Czech Central Bank. Retrieved on: December, 23, 2006: research_publications/cnb_wp/ download/cnbwp_2006_01.pdf.

Buiter, B. and Siebert, A. (2006). 'Beauties and the Beast: When will the new EU members from Central and Eastern Europe join the Euro zone?' Remarks prepared for the Conference "The ECB and its Watchers VIII", Friday May 5, 2006. Background paper @ www.nber.org/ buiter/beauties.

Christl, J. (2006). 'Regional Currency Arrangements: Insights from Europe', Bank of Greece, Working Paper No: 42.

De Grauwe, P. (2006). Economics of Monetary Union, $6^{\text {th }}$ edition. Oxford: Oxford University Press.

De Grauwe P. and Mongelli, P. (2005). 'Endogeneities of Optimum Currency Areas: What Brings Countries Sharing a Single Currency Closer Together?'. ECB Working Paper Series, No:468.

De Grauwe, P. (2002). 'The Challenge of the Enlargement of Euroland'. HM Treasury to revisit his 1996 paper 'Monetary Union and Convergence Economics'. Retrieved on: December 25, 2006, www.hmtreasury.gov.uk/media/AEE/C3/adkent03_678910_18.

De Grauwe, P. (2006a). 'What have we learnt about monetary integration since the Maastricht Treaty?'. Journal of Common Market Studies 44(4). 4, pp.711-730.

De Grauwe, P. (2006b). Preliminary Draft, 'On Monetary and Political Union', paper presented at seminar, May 2006. Retrieved on: 12 December 2006, www.financesinternationales.sciences-po.fr/seminaire conf/article_paul_de_rauwe.pdf.

De Grauwe, P. and Schnabl, G. (2005). Nominal Versus Real ConvergenceEMU Entry Scenarios for the New Member States. USA: Blackwell Publishing Ltd. 
Eichengreen, B. (2002). 'Reflections on the Coherence of the Euro Area' HM Treasury to revisit his 1992 article 'Shocking Aspects of European Monetary Unification' co-authored by Bayoumi, T., published by U.K Treasury (2003), "Submission on EMU from Leading Academics". Retrieved on: December 16, 2006, www.hm-treasury.gov.uk.

European Commission (2006). Annual Report on the Euro Area-2006. Brussels: European Commision.

Eurostat (2006) European Commisson: http://epp.eurostat.ec.europa.eu.

Fertig, M. And Schmidt, C. (2002). 'Mobility within Europe-What do we (still not) know?'. IZA Discussion Paper Series, No 447.

Fountas, S. and Papagapitos, A. (2001). "The monetary transmission mechanism: evidence and implications for European Monetary Union,' Economics Letters, 70 (2001), pp. 397-404

Frankel, J. (2002). 'The UK Decision Re EMU- Implications of Currency Blocks for Trade and Business Cycle Correlations', HM Treasury to revisit his 1998 paper co-authored with Andrew Rose 'The Endogenity of OCA' published by U.K Treasury (2003), "Submission on EMU from Leading Academics". Retrieved on: December 16, 2006, www.hmtreasury.gov.uk.

Frankel, J. and Rose, A. (1996). 'Economic Structure and the Decision to adopt a Common Currency, Revised Draft'. Institute for International Economic Studies, Stockholm University, S-WoPEc Scandinavian Working Papers in Economics, No: 611.

Fritz,B., Fink, G. and Haiss, P. (2004). 'How well prepared are the New Member States for the European Monetary Union?'. Journal of Policy Modeling, 26.

Gern, K-J., Hammermann, F., Schweickert, R. and de Souza,L. (2004). 'European Monetary Integration after EU Enlargement'. Kiel Discussion Papers 413, 26.

Haug, A., Mac Kinnon, J. and Michelis, L. (1999). 'European Monetary Union : A Cointegration Analysis'. Journal of International Money and Finance, 19(3), pp. 419-432.

Hein, E. and Truger, A. (2003). 'European Monetary Union: nominal convergence, real divergence and slow growth? Structural Change and Economic Dynamics 16(1), pp. 7-33. 
Hishow, O. (2006). 'The Euro- Engine or Brake of Europe's Economic Convergence'. SWP Berlin, Working Paper FGI.

Kenen, P. (2002). 'What we can learn from the Theory of optimum Currency Areas?' HM Treasury to revisit his 1969 paper 'The Theory of Optimum Currency areas: an Eclectic View', published by U.K Treasury (2003), "Submission on EMU from Leading Academics". Retrieved on: December 16, 2006, www.hm-treasury.gov.uk.

Krugman, P., Obstfeld, M. (2003). International Economics, Theory and Policy, ${ }^{\text {th }}$ Edition. New York: Addison Wesley.

Kucerova Z. (2003). 'The OCA Theory and its Application to Central and Eastern European Candidate Countries'. Retrieved on: December 23, 2006, www.soc.uoc.gr/ss6/ students_papers/Zuzana\%20Kucerova.pdf.

Kutan, A and Yiğit, T. (2004). 'Real and nominal stochastic convergence: Are the new EU members ready to join the Euro zone?'. Journal of comparative Economics, 33(2), pp.387-400.

Lavrac, V., (2004). 'Fulfillment of Maastricht Convergence Criteria and the Acceding Countries'. Eastward Enlargement of the Euro-zone Working Papers, Ezoneplus WP. 21. Retrieved on: December 9, 2006, http://www.ezoneplus.org /archiv /ezp_wp_21.pdf.

Mc Kinnon, R. (2002). 'Mundell, the Euro, and Optimum Currency Areas', Stanford University Working Paper Series No:00009. Retrieved on: December 15,2006, www-econ.stanford. edu/faculty/workp/ swp00009.pdf.

Mc Kinnon, R. (2004) 'Optimum Currency Areas and Key Currencies: Mundell I versus Mundell II'. Journal of Common Market Studies, 42(4)., pp.689-715.

Meister, I.S. (2002). 'Is Eastern Europe ready for the euro?: A cointegration analysis for the Maastricht criteria'. De Nederlandsche Bank Research Department, Research Memorandum WP no: 669.

Mongelli, F. (2005). 'What is European Economic and Monetary Union Telling us About the Properties of Optimum Currency Areas?'. Journal of Common Market Studies, 43(3). pp. 607-35.

Mundell, R. (1968). 'A Theory of Optimum Currency Areas'. International Economics. New York: Macmillan, pp.177-186. 
Mundell, R. (1997). Extended version of a luncheon speech presented at the Conference on Optimum Currency Areas, @ Tel-Aviv University on December 1997, Retrieved on: December 21, 2006, www.geocities.com/ Eureka/Concourse/8751/edisi04/ocata.htm

Prausello, F. (2004). 'Will Enlargement Put at Risk the Viability of EMU?' DISEFIN, Università di Genova, Faculty of Science Politics Working Paper no. 1/2004.

Soukiazis, E. and Castro, V. (2005). 'How the Maastricht Criteria and the Stability and Growth Pact affected the convergence process in the European Union. A panel data analysis.' Journal of Policy Modelling, 27. 